ORIGINAL RESEARCH ARTICLE

\title{
ISOLATION AND IDENTIFICATION OF Pseudomonas spp. TO CONTROL Plasmodiophora brassciae, THE PATHOGEN OF CLUBROOT DISEASE ON CABBAGE
}

\author{
I Ketut Suada* and Anak Agung Ngurah Gede Suwastika \\ Department of Agroecotechnology, Faculty of Agriculture, Udayana University, Bali \\ *Corresponding author: ketutsuada@unud.ac.id
}

Received : $9^{\text {th }}$ November $2016 \mid$ Accepted $: 3^{\text {rd }}$ February 2017

\begin{abstract}
Clubroot is very detrimental disease to cabbage production so as farmers work on various efforts to control it. The use of fungicides not only ineffective but also pollute the environment, therefore biological control system need to be pursued. The use of antagonistic agents such as Pseudomonas has been widely studied and known effective in suppressing various pathogens. Therefore it is worth trying its effectiveness against Plasmodiophora brassicae, a pathogen of cabbage. The purpose of this study was to obtain indigenous Pseudomonas which effectively suppress the pathogens and may also increase plant growth. Microbes were isolated from the cabbage area using the Kings'B medium with multilevel dilution. All isolates were tested for their effectiveness in pots in a Completely Randomized Design with a concentration of $1.5 \times 106$ CFU (Colony Forming Unit) per pot. The variables observed were plant growth, number of club roots, and percentage of disease incidence. Fourteen isolates of Pseudomonas were isolated. Three Pseudomonas isolates were found most effective at suppressing clubroot disease and increasing plant growth. The best isolate obtained was Pseudomonas-6, followed Pseudomonas-9, and Pseudomonas-8.
\end{abstract}

Keywords: cabbage, clubroot, Pseudomonas.

\section{INTRODUCTION}

Cabbage (Brassica olearacea var. capitata L.) is a source of vitamins A, B1, C, and minerals for the human body, so as the vegetable is very important to the people. Local Bali cabbage production has decreased from year to year. Cabbage production in Bali in 2010 amounted to 47,077 tons, 42,926 tons in 2011, in 2012 was 40,167 tons, and in 2013 was only 35,781 tons (BPS Bali, 2014). According to the local farmers, the decline is mainly due to a severe attack of clubroot pathogens on cabbage plants.
The use of pesticides is often ineffective for soil infectious pathogens especially clubroot pathogens and excessive use would highly polluting the environment. Increased public attention to environmental safety causes also limit the use of pesticides. Therefore, one of the most environmentally friendly alternative controls in suppressing the development of Plasmodiophora brassicae is biological control using microbes.

One potential antagonist bacteria that has been widely documented is $P$. 
fluorescens strain $\mathrm{CHAO}$, and has been shown very effective in suppressing various soil infectious diseases. Such strains can produce some substances such as $\mathrm{HCN}$ (Ganeshan and Kumar, 2005), phenazine-1carboxylic acid (PCA) antibiotic (Jaaffar et al., 2017), siderophore (Mousa and Raizada, 2016). that suppress various plant pathogens. The use of Pseudomonas in seeds or crops can significantly increase the growth and yield of crops in both greenhouse and field trials. Pseudomonas can be useful for many reasons including: 1) direct suppression of Pseudomonas to pathogen; 2) beneficial effects of other biocontrol agents such as mycorrhiza due to Pseudomonas in the soil; 3) increased availability of mineral nutrients for plants caused by Pseudomonas; 4) promotion of plant growth due to the growing substance produced by Pseudomonas on the association (Hayat, 2010; Pastor et al., 2010; Defago and Haas, 1990; Rovira et al.,1992; Paath and Ratulangi, 2014).

Of the entire microbial control agent testing, the various constraints of its effectiveness have been well documented. The main factors responsible to this decline are the growing environment of temperature fluctuation, ultraviolet light exposure, $\mathrm{pH}$ change, water and moisture availability, nutrition, and indigenous microflora competition (Couillerot, 2009; Walker, 2014;
Zhu, 2015). This all informations indicate that there is an adaptation problem of an introduced biological agent at an application site.

Biological control agents drawn from outside the introduction area will face various obstacles in their development. As mentioned above, the main constraint is the temperature and humidity in the new area so it is necessary to adapt the agents physiologically. As a result, these microbes are often no longer effective as pathogenic control agents. In addition, bacteria can rapidly change their genetic makeup so that its effectiveness also rapidly decreases.

Weller (1988) research on wheat has clearly concluded that initially, introduction agents can dominate in new places in the first week only, however by the end of the season the population is less than $2 \%$. Similarly, genetically engineered biological agents are also experiencing the same thing that the population will shrink drastically and eventually the biological agents can not grow hence can not to compete to others. Therefore it is necessary to look for indigenous microbes in a region, mass reproduced, then applied in the same area. The microbes will be used in their habitats so that there will not need to be much adaptation at the growth site. Therefore it is necessary to look for indigenous microbes in a region, reproduced, then applied in the 
area. The microbes will be used in their habitats so that there will not need to be much adaptation at the growth site. The purpose of this research is to obtain controlling agent of a certain strains of Pseudomonas spp. that are indigenous and effective in suppressing the development of $P$. brassicae pathogens of clubroot disease and simultaneously spurring the growth of cabbage plants.

\section{MATERIALS AND METHODS}

Examples of soil as a source of inoculums were taken from the vegetable growing region at Bedugul, Tabanan, Bali which is endemic to clubroot disease. Microbial isolation was carried out at Agricultural Biotechnology Laboratory Faculty of Agriculture Udayana University, Denpasar. The pot experiment was conducted in a green house of Experimental Field Station, Faculty of Agriculture, Jalan Pulau Moyo Denpasar.

Materials used in this study were examples of endemic soils, Kings'B media, $70 \%$ alcohol, and antibiotics to kill fungi. The equipments used are glass erlenmeyer, petri dish, laminar airflow cabinet, autoclave, pipette, plastic pot, microscope, and ultra violet light.

The isolation of Pseudomonas bacteria was performed by dilution method with dilution from $10^{-1}$ to $10^{-7}$. For the $10^{-1}$ dilutions, $1 \mathrm{~g}$ of the sample soil was put into a reaction tube containing $9 \mathrm{ml}$ sterile distilled water then vortexed. One $\mathrm{ml}$ of the soil suspension was transferred to a new reaction tube containing $9 \mathrm{ml}$ water, vortexed, to get $10^{-2}$ dilution. By the same steps there was a dilution rate of $10^{-7}$. Each dilution level was cultured as much $1 \mathrm{ml}$ in a sterile petri dish that filled with King's B medium containing 100 ppm novobiocyn and 100 ppm cyclohexamide. Furthermore, bacterial colonies that grew on King's B medium were observed under ultraviolet (UV) light. Pseudomonas was colony of green color luminescence. Subsequently, the colonies were subcultured to obtain pure isolate.

\section{Isolates testing}

In-vivo isolate testing was performed on plants in pots. A total of $2.5 \mathrm{~kg}$ of mixed media (endemic soil: compost fertilizer with a ratio of 3:1) is inserted into polybags with diameter of $12.5 \mathrm{~cm}$ and height of $20 \mathrm{~cm}$. A three (3) weeks old cabbage seedling was planted in each polybag. The plants were arranged in Completely Randomized Design with a treatment of the isolated Pseudomonas species. The treatment was applied with a concentration of $1.5 \times 10^{6} \mathrm{CFU}$ (Colony Forming Unit).

\section{Variables}

The variables observed include plant height, measured from the soil surface to the highest leaf tip after being pushed upward; 
number of leaf; the number of root gall, calculated after the plant was revoked; percentage of disease incidence, calculated from the number of plants having gall after the plant was revoked; leaf chlorophyll content, measured by a chlorophyll meter device; leaf area, measured with Leaf Area Meter. All these variables were observed at 8 WAP (weeks after planting).

\section{Data analysis}

The data were analyzed according to the Complete Randomized Design (CRD) used and followed by Duncan Multiple Range Test at level of $1 \%$ and $5 \%$.

\section{Plant maintenance}

Plants were watered twice a day to maintain its field capacity. Fertilization was done 2 times at 1 WAP and 5 WAP with a dose of $1.3 \mathrm{~g} / \mathrm{plant}$ ZA, $1.8 \mathrm{~g} / \mathrm{plant}$ TSP, and $0.7 \mathrm{~g} / \mathrm{plant} \mathrm{KCl}$.

\section{RESULTS AND DISCUSSION}

\section{Bacterial isolates}

Pseudomonas bacteria were found in the rhizosphere of some types of plants in the study site which were suspected as antagonists of clubroot pathogen. When observed under ultraviolet light, the bacterial colony appears green light. The green color occurs due to the luminescence of fluorescens compounds from bacteria which metabolize the pepton components of the Kings'B medium. The characteristics of colonies are presented in Table 1. Visually the bacterial colonies found can be seen as Fig. 1.

Table 1. Colony characteristics of Pseudomonas bacteria found in rhizosphere of various plants

\begin{tabular}{|c|c|c|c|}
\hline \multirow{2}{*}{ Isolates } & \multicolumn{3}{|c|}{ Colony performance } \\
\hline & Form & Ledges & Elevation \\
\hline $\begin{array}{l}\text { Pseudomonas }-0 \\
\text { (without isolate) }\end{array}$ & $\begin{array}{l}\text { Irregular } \\
\text { and spreading }\end{array}$ & $\begin{array}{l}\text { not } \\
\text { grooved }\end{array}$ & arise \\
\hline Pseudomonas-1 & Round & smooth & flat \\
\hline Pseudomonas-2 & Round & smooth & umbonate \\
\hline Pseudomonas-3 & Round & smooth & buttons like \\
\hline Pseudomonas-4 & Round & smooth & flat \\
\hline Pseudomonas-5 & Irregular & $\begin{array}{l}\text { not } \\
\text { grooved }\end{array}$ & flat \\
\hline Pseudomonas-6 & Round & smooth & arise \\
\hline Pseudomonas-7 & Round & smooth & flat \\
\hline Pseudomonas-8 & Round & smooth & umbonate \\
\hline Pseudomonas-9 & Round & smooth & flat \\
\hline Pseudomonas-10 & Round & smooth & umbonate \\
\hline Pseudomonas-11 & Round & smooth & umbonate \\
\hline Pseudomonas-12 & Round & smooth & flat \\
\hline Pseudomonas-13 & Round & smooth & umbonate \\
\hline Pseudomonas-14 & Round & smooth & arise \\
\hline
\end{tabular}


Description: The numbers following words "Pseudomonas" is isolate number that isolated from various plants rhizosphere.

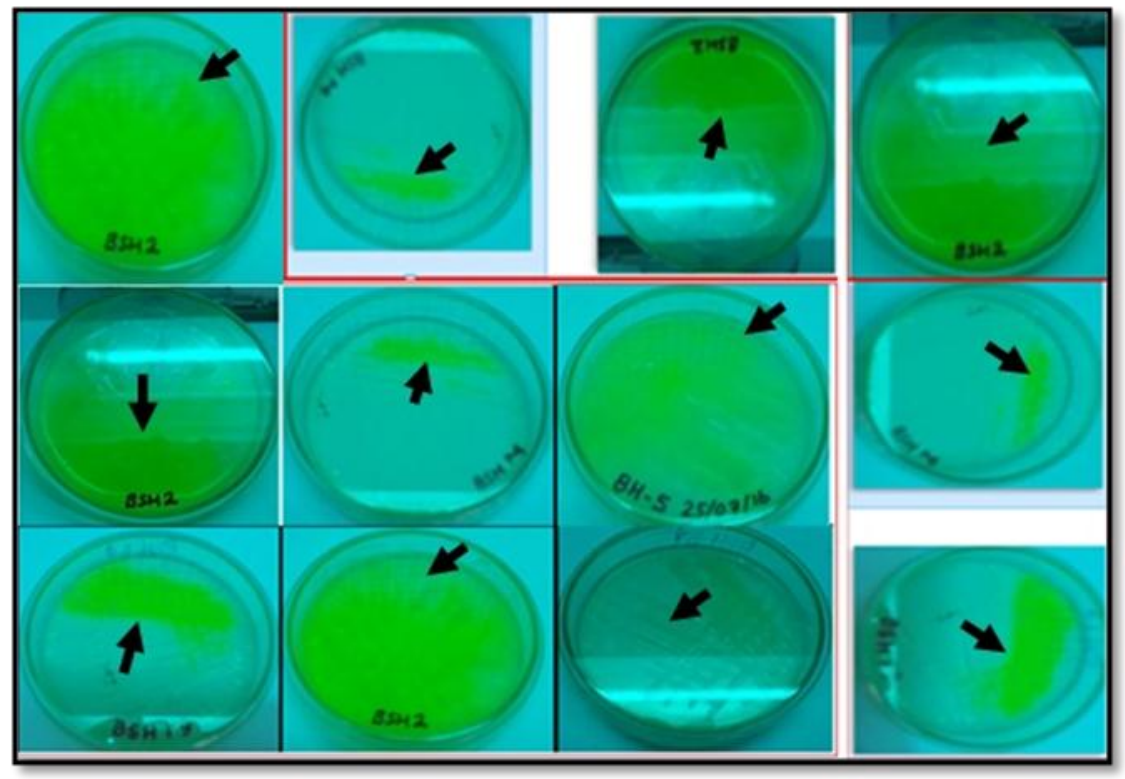

Fig. 1. Pseudomonas spp. isolated from various plants rhizosphere. (Glowing greenish color under UV light, arrow sign)

\section{Effect of Pseudomonas spp. isolates}

Cabbage plant performance observed were plant height, leaf number, leaf area, and leaf chlorophyll content. Against all these variables, different Pseudomonas isolates may have different effects (Table 2). Isolates that give the highest (the best) effect on all of these variables except the number of leaflets was isolate Pseudomonas-6 isolated from red lettuce rhizosphere. The amount of leaf chlorophyll due to Pseudomonas-6 was the highest i.e. 6778.85 SPAD followed by Pseudomonas-9, Pseudomonas-8, Pseudomonas-4, and Pseudomonas-7 with values of 3953.88 SPAD, 3739.26 SPAD, 3538.55 SPAD, and 3350.84 SPAD respectively. These all suggested a positive interaction between cabbage plants and Pseudomonas spp. to spur plant growth.

This also means that Pseudomonas-6 can greatly increase plant growth. One indicator of good plant growth was the leaf chlorophyll content. 
ISOLATION AND IDENTIFICATION OF Pseudomonas spp. TO CONTROL Plasmodiophora brassciae, THE

PATHOGEN OF CLUBROOT DISEASE ON CABBAGE

I Ketut Suada and Anak Agung Ngurah Gede Suwastika

Table 2. Effect of Pseudomonas spp. isolate against plant performance

\begin{tabular}{|c|c|c|c|c|}
\hline \multirow[b]{2}{*}{ Treatment } & \multicolumn{4}{|c|}{ Plant performance } \\
\hline & $\begin{array}{l}\text { Plant } \\
\text { height } \\
(\mathrm{cm})\end{array}$ & $\begin{array}{c}\text { Total leaf } \\
\text { (sheet) }\end{array}$ & $\begin{array}{c}\text { Leaf area } \\
\left(\mathrm{cm}^{2}\right)\end{array}$ & $\begin{array}{c}\text { Leaf } \\
\text { chlorophyll } \\
\text { (SPAD) }\end{array}$ \\
\hline $\begin{array}{l}\text { Pseudomonas-0 } \\
\text { (without isolate) }\end{array}$ & $14,91 \mathrm{c}$ & $9,38 \mathrm{c}$ & $51,02 \mathrm{c}$ & $1709,17 \mathrm{~d}$ \\
\hline Pseudomonas-1 & $14,97 \mathrm{c}$ & $9,44 \mathrm{~b}$ & $51,16 \mathrm{~d}$ & $1692,37 \mathrm{~d}$ \\
\hline Pseudomonas-2 & $18,81 \mathrm{ab}$ & $9,55 \mathrm{~b}$ & 83,82 bcd & $2832,27 \mathrm{~cd}$ \\
\hline Pseudomonas-3 & $19,39 a b$ & $10,89 \mathrm{a}$ & $78,05 \mathrm{bcd}$ & $2674,77 \mathrm{~d}$ \\
\hline Pseudomonas-4 & $19,53 \mathrm{ab}$ & $9,55 \mathrm{~b}$ & $102,30 \mathrm{bc}$ & $3538,55 \mathrm{bc}$ \\
\hline Pseudomonas-5 & $18,20 \mathrm{~b}$ & $9,77 \mathrm{ab}$ & 89,19 bcd & $3125,21 \mathrm{c}$ \\
\hline Pseudomonas-6 & $20,57 \mathrm{ab}$ & $9,67 \mathrm{ab}$ & $198,27 \mathrm{a}$ & $6778,85 \mathrm{a}$ \\
\hline Pseudomonas-7 & $20,05 \mathrm{ab}$ & $9,77 \mathrm{ab}$ & $98,15 \mathrm{bc}$ & $3350,84 \mathrm{c}$ \\
\hline Pseudomonas-8 & $19,53 \mathrm{ab}$ & $10,11 \mathrm{ab}$ & $107,45 \mathrm{bc}$ & $3739,26 \mathrm{bc}$ \\
\hline Pseudomonas-9 & $20,24 \mathrm{ab}$ & $9,44 \mathrm{~b}$ & $115,78 \mathrm{~b}$ & $3953,88 \mathrm{~b}$ \\
\hline Pseudomonas-10 & $19,41 \mathrm{ab}$ & $9,44 \mathrm{~b}$ & $65,98 \mathrm{~cd}$ & $2234,74 \mathrm{~d}$ \\
\hline Pseudomonas-11 & $18,97 \mathrm{ab}$ & $9,67 \mathrm{ab}$ & 84,84 bcd & $2890,49 \mathrm{~cd}$ \\
\hline Pseudomonas-12 & $19,06 \mathrm{ab}$ & $10,22 \mathrm{ab}$ & $74,28 \mathrm{bcd}$ & $2525,52 \mathrm{~d}$ \\
\hline Pseudomonas-13 & $21,12 \mathrm{a}$ & $9,67 \mathrm{ab}$ & $93,24 \mathrm{bc}$ & 3204,65 c \\
\hline Pseudomonas-14 & $20,04 \mathrm{ab}$ & $9,44 \mathrm{~b}$ & 84,21 bcd & $2783,14 \mathrm{~cd}$ \\
\hline Pseudomonas-15 & $19,50 \mathrm{ab}$ & $9,78 \mathrm{ab}$ & $85,28 \mathrm{bcd}$ & $2925,10 \mathrm{~cd}$ \\
\hline
\end{tabular}

Description: The numbers followed by the same letter in the same column means not significantly different based on Duncan Multiple Range Test at 5\% levels.

The high amount of chlorophyll in the leaves shows the high activity of photosynthesis. Carbohydrates will form more in leaves with high chlorophyll content. More carbohydrates formed will provide the material for subsequent metabolism to produce substance of cell components; hence the plant growth will be faster or better and even healthier in more leaf chlorophyll. Meanwhile, the hormone which formed due to the Pseudomonas-6 in association to plants may encourage the growth of plants in basis of high cell component produced in metabolism/photosynthesis.
Rapid plant growth occurs due to Pseudomonas activities. The bacteria can stimulate plant growth, increase the availability of plant minerals, and produce growth regulators for its host (Alemu and Alemu, 2015; Iqbal and Hasnain, 2013).

\section{Percentage of attacks}

Symptoms of the disease attack occurred in this experiment was a day withered plants and gall formed on the roots. Swollen roots clog the flow of water/nutrients to the leaves hence the plant looks wilted during the day (Fig. 2). 


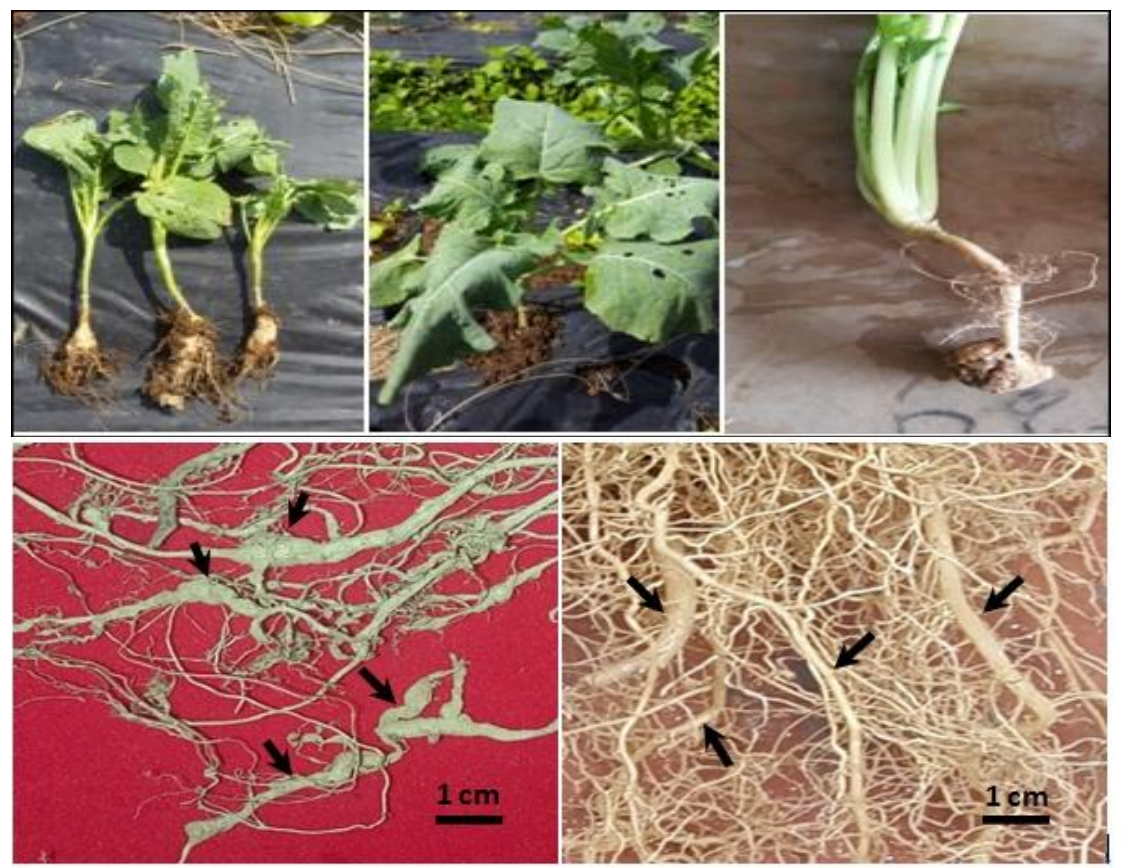

Fig. 2. Symptoms of clubroot disease on cabbage. Plant wilting on the daytime (upper middle) due to roots swelling (left and right above), swelling root symptoms (bottom left), and healthy roots (bottom right).

The lowest of attacks percentage occurred in the treatment of isolates Pseudomonas-6 which isolated from red lettuce (Lactuca sativa var. crispa L.). The percentage of attacks of the isolat was zero $(0 \%)$ with the same value to Pseudomonas-9, followed by Pseudomonas-8 and Pseudomonas-4 with an attack percentage of $11 \%$ respectively (Table 3).

According to Defago and Keel (1995), Nagaraj Kumar et al. (2004), and Fekria et al. (2015) that the protection system by Pseudomonas is manifested through mechanisms such as 1) colonizing the roots so that the roots are physically and chemically protected, 2) antibiosis through chemical compounds released by bacteria such as $\beta-1,3$-glucanase, chitinase enzymes, salicylic acid, and cyanide acids, 3) competition for iron (siderophore mechanism); 4) degradation of pathogenicity and germination of pathogen inoculum; 5) stimulate plant growth through bacteriagrowing substances; and 6) through plant resistance induction. 
Table 3. Percentage of attack of clubroot pathogens on cabbage treated by Pseudomonas spp. isolates

\begin{tabular}{|c|c|c|}
\hline \multirow{2}{*}{$\begin{array}{c}\text { Treatments } \\
\text { (Isolate number) }\end{array}$} & \multicolumn{2}{|c|}{ Variables } \\
\hline & Total gall (pieces) & $\begin{array}{c}\text { Attack percentage } \\
(\%)\end{array}$ \\
\hline Pseudomonas-0 (without isolate) & $8,44 \mathrm{a}$ & $100,00 \mathrm{a}$ \\
\hline Pseudomonas-1 & $7,78 \mathrm{a}$ & $44,44 \mathrm{bc}$ \\
\hline Pseudomonas-2 & $7,44 \mathrm{a}$ & $66,66 \mathrm{ab}$ \\
\hline Pseudomonas-3 & $8,22 \mathrm{a}$ & $100,00 \mathrm{a}$ \\
\hline Pseudomonas-4 & $5,33 \mathrm{~b}$ & $11,11 \mathrm{de}$ \\
\hline Pseudomonas-5 & $7,89 \mathrm{a}$ & $55,55 \mathrm{ab}$ \\
\hline Pseudomonas-6 & $0,00 \mathrm{c}$ & $0,00 \mathrm{e}$ \\
\hline Pseudomonas-7 & $7,35 \mathrm{a}$ & $33,33 \mathrm{bc}$ \\
\hline Pseudomonas-8 & $4,33 \mathrm{~b}$ & $11,11 \mathrm{de}$ \\
\hline Pseudomonas-9 & $0,00 \mathrm{c}$ & $0,00 \mathrm{e}$ \\
\hline Pseudomonas-10 & $7,78 \mathrm{a}$ & $55,55 \mathrm{ab}$ \\
\hline Pseudomonas-11 & $7,78 \mathrm{a}$ & $44,44 \mathrm{~b}$ \\
\hline Pseudomonas-12 & 8,56 a & $100,00 \mathrm{a}$ \\
\hline Pseudomonas-13 & $7,56 \mathrm{a}$ & $100,00 \mathrm{a}$ \\
\hline Pseudomonas-14 & $7,44 \mathrm{a}$ & $33,33 \mathrm{bc}$ \\
\hline Pseudomonas-15 & $7,44 \mathrm{a}$ & $100,00 \mathrm{a}$ \\
\hline
\end{tabular}

Description: The average number followed by the same letters in the same column is not significantly different based on Duncan Multiple Range Test at 5\% levels. The percentage of attack data was analyzed after converted to $\operatorname{arc}-\sin \sqrt{ }(x+1 / 2)$.

Although there are several different colony structures, the invisible colors of the isolates can not be distinguished, all of which appear green under ultraviolet light. However, due to its different effectiveness on some plant variables, the isolates are physiologically likely to be different, for example in the species form or strain. Due to its inability to distinguish microscopically it is necessary to be analyzed molecularly hence the isolates can be identified appropriately.

\section{ACKNOWLEDGEMENT}

The authors wish to thank Rector of Udayana University for financial support through Research and Community Service for Prosperity. The authors also expressed the appreciation to the Faculty of Agriculture of Udayana University for its laboratory support. Special thanks are addressed to all my students for data collections so as this research can be finished on time.

\section{REFERENCES}

Alemu, F., \& Alemu, T. (2015). Pseudomonas fluorescens isolates used 
as a plant growth promoter of faba bean (Vicia faba) in vitro as well as in vivo study in Ethiopia. American Journal of Life Sciences. 3(2):100-108. doi: 10.11648/j.ajls.20150302.17.

BPS Bali. (2014). Produksi Sayur-sayuran Menurut Kabupaten/Kota di Bali. <http://bali.bps.go.id/tabel_detail.php? ed $=607005 \&$ od $=7 \& \mathrm{id}=7>$ [20/02/2016].

Couillerot, O., Prigent-Combaret, C, Caballero-Mellado, J., \& MoenneLoccos, Y. (2009). Pseudomonas fluorescens and closely-related fluorescent pseudomonads as biocontrol agents of soil-borne phytopathogens. Applied Microbiology 48:505-512.

Defago, G., \& Haas, D. (1990). Pseudomonads as antagonist of soilborne plant pathogens: mode of action and genetic analysis. Pages 249291 in: Soil Biochem. 6. J.M. Bollag and G. Stotzky, eds. Marcell Decker, New York.

Defago, G., \& Keel, C. (1995). Pseudomonads as biocontrol agents of diseases caused by soil-borne pathogens. pp. 137-148 in Hokkanen HMT, Lynch JM (eds), Biological Control: Benefits and Risks. Plant and Microbial Biotechnology Research Series 4. Cambridge University Press. ISNB 9780521544054.

Fekria, M. A., Saber, F. M. A., Ahmed, A., Abdelhafez, E. A., Hassan \& E. M. Ramadan. (2015). Characterization of fluorescent pseudomonads isolates and their efficiency on the growth promotion of tomato plant. Annals of Agricultural Sciences 60(1):131-140.

Ganeshan, G., \& Kumar, A. M. (2005). Pseudomonas fluorescens, a potential bacterial antagonist to control plant diseases. Journal of Plant Interactions. 1(3):123-134.

Hayat, R., Ali, S., Amara, U., Khalid, R., \& Ahmed, I. (2010). Soil beneficial bacteria and their role in plant growth promotion: a review. Annals of Microbiology 60(4):579-598.

Iqbal, A., \& Hasnain, S. (2013). Auxin producing Pseudomonas strains: biological candidates to modulate the growth of Triticum aestivum beneficially. American Journal of Plant Sciences, 4:1693-1700.

Jaaffar, A.K.M., J.A. Parejko, T.C. Paulitz, D.M. Weller, and L.S. Thomashow. (2017). Sensitivity of Rhizoctonia isolates to phenazine-1-carboxylic acid and biological control by phenazineproducing Pseudomonas spp. Phytopathology 107(6):692-703. <https://doi.org/ 10.1094/PHYTO-0716-0257-R>. [15/07/2017].

Kumar, N. M., Bhaskaran, R., \& Velazhahan, R. (2004). Involvement of secondary metabolites and extracellular lytic enzymes produced by Pseudomonas fluorescens in inhibition of Rhizoctonia solani, Microbiological Research, 159: 73-81.

Mousa, W. K., \& Raizada, M. N. (2016). Natural Disease Control in Cereal Grains. pp 257-263. In: Wrigley, C., H. Corke, K. Seetharaman, and J. Faubion (ed.). Encyclopedia of Food Grains, $2^{\text {nd }}$ Ed. Oxford: Academic Press.

Paath, J. M., \& Ratulangi, M. (2014). The Application of Trichoderma koningii and Fluorescent-pseudomonas to control diseases on chili in Minahasa, North Sulawesi. Fitopatologi 10(4):133-137. DOI: 10.14692/jfi.10.4.133.

Pastor, N. A., M.M. Reynoso, M.L. Tonelli, O. Masciarelli, S.B. Rosas, and M. Rovera. (2010). Potential biological control Pseudomonas sp. PCI2 against damping-off of tomato caused by Sclerotium rolfsii. Plant Pathology 92(3):737-745.

Rovira, A. D., Ryder, H. M., \& Harris, A, R. (1992). Biological control of root diseases with pseudomonads. In: Tjamos ES, G.C. Papavizas, R.J. Cook (eds.). Biological Control of Plant Diseases-Progress and 
Challenges for the Future. New York, USA: Plenum Press, 175-184.

Walker. (2014). Multiple soil nutrient competition between plants, microbes, and mineral surfaces: Model development, parameterization, and example applications in several tropical forests.

Weller, D. M. (1988). Biological control of soilborne pathogens in the rhizosphere with bacteria. Annual Review of Phytopathology 26, 379-407.

Zhu, (2015). Interactive comment on multiple soil nutrient competition between plants, microbes, and mineral surfaces: model development, parameterization, and example applications in several tropical forests. Biogeosciences 12:C4306-C4312. 